2016-04

\title{
John Wolcot and "The Anecdotic Itch": Peter Pindar, Biography, and Historiography in the 1780s
}

\section{Moore, D}

http://hdl.handle.net/10026.1/4490

\subsection{5/00982601-3483900}

Eighteenth-Century Life

All content in PEARL is protected by copyright law. Author manuscripts are made available in accordance with publisher policies. Please cite only the published version using the details provided on the item record or document. In the absence of an open licence (e.g. Creative Commons), permissions for further reuse of content should be sought from the publisher or author. 
8 John Wolcot, under his nom de plume of Peter Pindar, was one of the most widely read

9 poets of the late eighteenth century: his 50 odd poetic satires on divers subjects were one

10 of the publishing phenomena of the age, with William Wordsworth, who generally

11 affected a low opinion of Wolcot, forced to consider him as one of the 'great names' of

12 satire. ${ }^{1}$ If the scale of his popularity was likely subject to some contemporary hyperbole,

13 nevertheless Donald Kerr's analysis of Wolcot's papers bears out the notion of Peter

14 Pindar as a highly profitable publishing enterprise in which the book trade had significant

15 commercial confidence. ${ }^{2}$ Despite (or in part because of) this ubiquity, Wolcot has been

16 neglected by scholarship, written off as a commercially-motivated trimmer devoid of

17 principle or any commitment to higher ideals; a 'literary gadfly', in the words of Jeanne

18 Griggs, 'harmless but irritating' who expended his talent on unworthy matters at a time of 19 national emergency. ${ }^{3}$

20 Some, particularly more recent, accounts of Wolcot have sought a more

21 sympathetic or complex response to his satiric method and output. ${ }^{4}$ Efforts devoted to the

22 critical rehabilitation of Wolcot have broadly fallen into two camps. The first, and larger,

23 effort has looked to ascribe a politically meaningful and radical value to a satiric method

24 that otherwise seems unduly invested in the treatment of trivial matters in a frivolous 
25 fashion. Gary Dyer has interpreted Wolcot's refusal 'to treat satire, in neo-Juvenalian

26 fashion, as a duty in a time of crisis' not as a moral failing or ducking of the important

27 issues of the day, but instead as a refusal of the normative and inherited modes of satire

28 and therefore as an anti-establishment gesture itself. ${ }^{5}$ John Barrell has argued that the

29 tone of good natured ribbing inherent in Wolcot's satire made it more not less subversive,

30 not least because it allowed Wolcot's views to reach a wide range of audiences, including

31 ones that were unreceptive to more strident and openly radical messages. ${ }^{6}$ There is indeed

32 evidence that Wolcot cultivated an image of innocuousness. In the ninth Expostulatory

33 Odes Peter compares himself unfavourably with Charles Churchill. Churchill is a 'first

34 rate man of war' compared to Peter's 'small cockboat bobbing at an anchor'; a

35 'blacksmith's sledge' compared to Peter's 'sugar hammer'. Yet ironic disavowals and

36 self-deprecation are amongst the more common currencies in which the satirist trades,

37 and here Wolcot ensures an association with Churchill that might not otherwise have

38 been apparent since suggesting that they should not be mentioned in the same breath

39 involves mentioning them in the same breath. The second sort of rehabilitation, best

40 exemplified by Benjamin Colbert's 'Petrio-Pindarics' and Iain McCalman's overview of

41 Wolcot, has sought to understand Wolcot's reputation and neglect in terms of the

42 emerging (self) image of the Romantic canon. Colbert highlights Wolcot's unnerving (for

43 the established Romantic view of the poet) interest in the demands of commercial print

44 culture, while McCalman draws attention to Wolcot's liminal (to his disadvantage)

45 position within the conventional ways in which literary history is periodised. ${ }^{7}$ These are

46 all significant interventions, but overall it remains the case that Wolcot is not as notable a

47 beneficiary as some of his contemporaries of a wider critical project that has, in the words 
48 of Steven E. Jones, worked to 'decentre Romanticism and reorientate its canonical works

49 and authors. ${ }^{8}$ In 1999 McCalman's verdict was that Wolcot 'remains seriously

50 underestimated by modern social historians and literary scholars', and while today one

51 might not put it in quite such stark terms, nevertheless he remains a neglected figure

52 relative to his presence in his day. ${ }^{9}$

53 This article takes its cue from these various approaches while also breaking new

54 ground in the ways Wolcot can be read. Informed by the previously central question of

55 Wolcot's politics as determined by the question of whether he is an anti-establishment or

56 toothless writer, it will consider key Peter Pindar satires of the 1780s in terms of

57 Wolcot's interest in the use of anecdote within the writing of history and biography and

58 his self-conscious interest in the business (figurative but also literal) of writing about

59 Great Men. Through these interests, I shall argue, Wolcot is engaging in significant

60 cultural debates about the meaning of greatness and significant achievement in the 1780s.

61 Appreciating this engagement broadens our sense of the questions it is possible to pose

62 about Wolcot as a writer beyond those to do with an attitude to ministerial policy during

63 the Revolutionary period.

64 The essay is in four parts. The first section offers a relatively brief and necessarily

65 broad outline of the immediate intellectual contexts of anecdote, history, politeness and

66 commerce that provide the framework for the reading of Wolcot that follows. The aim is

67 here to demonstrate how these various cultural and intellectual dynamics can be seen in

68 vital relation to Wolcot's work. The middle two sections offer reciprocal case studies of

69 these matters. The first considers two poems in which Peter Pindar addresses the

70 questions provoked by efforts to memorialise a figure of stature in the literary world in 
71 the shape of the recently departed Samuel Johnson: A Poetical and Congratulatory

72 Epistle to James Boswell, Esq on his Journal of a Tour to the Hebrides with the

73 celebrated Dr Johnson (1786); and Bozzy and Piozzi, or, The British Biographers, A

74 Town Eclogue (1786). In these poems we shall see how Johnson can only be understood,

75 and writing about him can only be guaranteed an audience, by focussing on the lowest-

76 common-denominator of scurrilous detail and base indignity. This is diagnosed as the

77 result of mass print culture, an obsession with gossip, and a base philistinism, the last of

78 which best encapsulated in the figure of King George III himself. If these poems set the

79 terms of the question or dilemma, my second set of examples offer Peter Pindar's own

80 solution to the question of mediating figures of eminence in the relationship he constructs

81 between poet (and satirist) and monarch, in his various poems of 1787 offering advice to

82 the Poet Laureate Thomas Warton with a particular focus on Instructions to a Celebrated

83 Laureat; alias The Progress of Curiosity; alias A Birthday Ode; alias Mr Whitbread's

84 Brewhouse. In this poem the critique of the King offered in the Celebratory Epistle is

85 extended but also inverted as Peter not only warms to his theme of royal imbecility but

86 suggests, in his reproach to Warton, that this is the only fitting way to write about the

87 King in a world where the values George represents defy the conventional language and

88 attributes of greatness. Or to put it another way, in Bozzy and Piozzi, the eponymous

89 biographers are chastised for writing mundane and trivial nonsense; in the Instructions

90 and Advice, Warton is chastised for writing anything other than mundane and trivial

91 nonsense. Separately the two sets of poems identify a mismatch between the subject of

92 the panegyric (be it Johnson or King George) and the grounds for, and manner of, the

93 celebration. Collectively they diagnose a wider cultural malaise to do with the meaning 
94 and mediation of stature and what might count as significant achievement amongst a

95 polite and commercial people. The essay will conclude with a final section summarising

96 these findings and discussing how the issues explored might knit back into the issues

97 outlined at the start of the introduction to do with Wolcot's place within late eighteenth-

98 century literary studies.

99

100

\section{I. "The Anecdotic Itch": History, Commerce, Virtue and the place of}

\section{Anecdote}

102

103 The use of the anecdotal method within the writing of history and biography in the

104 eighteenth century has been the subject of significant recent enquiry. Such enquiries have

105 tended to stress the multiple uses and interpretations available to the eighteenth century,

106 something that Lionel Grossman, in his comprehensive anatomy of the anecdote and its

107 various forms, calls, with admirable understatement, 'a complex matter'. ${ }^{10}$ Rebecca

108 Bullard's discussion of secret history narratives (to which the anecdotal method is closely

109 allied etymologically and practically in the early eighteenth century) is perhaps most

110 notable for arguing, in the face of previous interpretations, that 'there is no intrinsic

111 connection between secret history and radical whig politics', but for the purposes of my

112 engagement with Wolcot, this is less important than her approach to thinking about the

113 secret - unsanctioned or unofficial - history as a 'rhetorical act of revelation', and a self-

114 conscious one at that. ${ }^{11}$ In what follows we shall see how Bullard's reading of secret

115 history as a discourse that 'scrutinizes the ethical, epistemic, historiographical and

116 political implications of its own revelatory gestures' chimes with Peter Pindar's highly 
117 self-conscious examination of the most appropriate way of capturing the deeds of great

118 men and the implications of his chosen approach. In this way his anecdotal approach

119 offers an unusual but identifiable addition to the discourse of secret history during the

120 eighteenth century.

121 As Grossman notes, the connection between anecdote and the revelatory secret

122 history loosened through the eighteenth-century (without, as we shall see, entirely losing

123 touch with it). The term lost its specific sense of embarrassing revelation about the

124 powers-that-be and gained a wider currency as part of a historiographical method

125 evolving in response to the priorities of a polite and commercial age. As the political and

126 social priorities of civic humanism gave way to those of commercial humanism notions

127 of moral and political virtue underwent a profound shift. To cite one just one famous

128 example, this is Samuel Johnson on the 'projectors':

129 I cannot conceived why he that has burnt cities, and wasted nations, and filled the

130 world with horror and desolation should be more kindly regarded by mankind

131 than he that died in the rudiments of wickedness; why he that accomplished

132 mischief should be glorious, and he that only endeavoured it should be criminal. ${ }^{12}$

133 By 'huddl[ing] together in obscurity and detestation' both those conventionally

134 considered the heroes of history and those failed criminals - both the Caesars and the

135 Catilines, as he puts it - Johnson is revaluing the meaning of virtue for an age repelled by

136 the warrior ethics of the past. This suspicion about the public actions of those that had

137 previously been considered the heroes of history is also accompanied by a

138 reconsideration of the proper materials of history. As history came to be understood not

139 as the civic activity of the autonomous citizen but as the result of a complex series of 
140 inter-relations, so understandings of the drivers of history and the ways in which history

141 should be articulated changed. This, in the words of Mark Salber Phillips, led to an

142 'enlargement of the boundaries of the historical' in order to take account for all those

143 things excluded from classical history but which commercial eighteenth-century Britain,

144 extrapolating from its own experience, saw as vital to the understanding of the past,

145 included 'the history of literature, of the arts and sciences, of manners and customs, even

146 of opinion and sentiment'. ${ }^{13}$ For Phillips, one symptom of this is the growth in

147 importance of the sentimental biography as one of the constituent genres of history in the

148 late eighteenth century, private histories containing anecdotal scenes of everyday life and

149 of the domestic sphere not, as at the start of the century, as a way of revealing the sordid

150 motivations and immoral priorities behind the pieties of official public history, but out of

151 a growing sense that manners maketh the man. At such a cultural moment, anecdote can

152 serve as a way of recovering what Helen Deutsch has termed 'a lost embodied "real", an

153 undoing of larger, public historical narratives in order [...] to bring the dead, particularly

154 the illustrious scholarly dead, back to life. ${ }^{14}$

155 Johnson had made this point forcefully three years early than his comments in The

156 Adventurer in The Rambler 60 . There he argues against the limiting perspectives of

157 public history and its 'false measures of excellence and dignity' (some of which he would

158 consider criminal in the later article) in favour of 'domestic privacies, and $[\ldots]$ the minute

159 details of daily life, where exterior appendages are cast aside, and men excel each other

160 only by prudence and virtue. ${ }^{15}$ Yet Johnson recognises the challenges of such a history.

161 Challenges to do with the selection of material, since not everything that can be known is

162 worth knowing; and the challenges of perspective that comes from a position intimate 
163 enough to its subject to be aware of those private habits worth knowing but able to retain

164 an independent and larger perspective, one that avoids seeing it 'an act of piety to hide

165 the faults and failings of their friends'. The answer, according to Johnson, remains firmly

166 rooted in the classical notion of history as exemplar, or, as he puts it with a Horation

167 rather than Plutarchean turn, to provide 'instruction or delight.' However, while Johnson

168 rests on this Horation editorial principle, Isaac Disraeli, in the most famous account of the

169 anecdote in England in the eighteenth century, goes one stage further in examining the

170 potential crisis of editorial judgement and priority within the anecdotal valuing of the

171 small details of life, a crisis summarised by Helen Deutsch as, 'if details like these are

172 important enough to record, then nothing is sacred, on the one hand, and nothing is

173 meaningless, on the other., 16

174 Disraeli is as clear as Johnson had been that if the proper study of history is the

175 human mind, then 'human nature, like a vast machine, is not to be understood by looking

176 at its superficies, but by dwelling on its minute springs and wheels. ${ }^{17}$ Disraeli maintains

177 that anecdote represents the essential means by which one understands the genius of men

178 and times and he therefore denies (in a way that Johnson perhaps would have done) that

179 there can ever be too many anecdotes collected and presented. Nevertheless he is clear

180 that it is the presentation of anecdote, its interpretation and the larger truths to which it is

181 taken to attest, that really matters. 'To collect anecdote is the humble labour of industry'

182 he suggests, the challenge if 'to present them with reflection, with acumen, and with

183 taste. ${ }^{18}$ In Disraeli's ideal anecdotal memoir, the memoirist collects exemplary episodes

184 and stories and presents them in such a way as to render himself invisible. The aim is to

185 set narrative and interpretation and anecdote off to such effect as to give the reader the 
186 illusion of discovering the company of the great man for themselves rather than to insist

187 upon the activities of the memoirist. In this way the anecdotal is central to what David

188 Simpson calls a 'culture of subjectification' and the emergence of 'middle class ideology'

189 during the period, not only because of the emphasis on the familiar and everyday closes

190 the gap between the traditionally elite and a middle class audience but also because of the

191 interpretative reading such an approach encourages: 'to make significant meaning out of

192 fragments or anecdotes is to make a self for ourselves in the very act of so making., 19

193 Johnson and Disraeli both demonstrate a confidence and anxiety about the role of

194 what had hitherto been secret history to provide an account of men and times more

195 aligned with the values of their times. Indeed those values themselves were a matter of

196 contest. As J.G.A. Pocock reminds us (and as Phillips's book amongst others charts)

197 'there is no greater and no commoner mistake in the history of social thought than to

198 suppose that the tension [between commercial and civic virtue] ever disappeared' ${ }^{20}$ The

199 superiority ascribed to polite and commercial society was tempered by a nostalgia - and

200 more in some quarters - for virtues it was easier to disavow than necessarily do without.

201 Reconciling sensibility and power was a key preoccupation of the middle decades of the

202 century across various fields and numerous texts can be read in this light: the moral and

203 political philosophy of Adam Smith and Adam Ferguson; the novels of Samuel

204 Richardson; the Poems of Ossian, which celebrate the impossible deeds of an impossible

205 hero who, in the words of Walter Scott, combined 'the strength and bravery of Achilles,

206 with the courtesy, sentiment and high-breeding of Sir Charles Grandison'. ${ }^{21}$ The 1780s in

207 particular saw increased anxieties, in the wake of the loss of the American colonies and

208 renewed threats to British interests in India that the fruits of a commercial empire would 
209 be moral corruption and inexorable decline. For example, Robert W Jones has

210 demonstrated the various ways in which the literature and politics of Opposition sought a

211 range of masculine identities and rhetorical forms that met the challenges of commerce

212 and politeness during a disastrous war. ${ }^{22}$ In this context the anecdotal is both an emblem

213 of the more expansive world of commerce and trade, of a complex, rich and sophisticated

214 society needing to be understood in terms of the 'secret springs' that motivate the actions

215 of complex modern individuals whose best and worst features were to be understood

216 within the everyday and domestic, and also a symptom, in Grossman's words, of 'the

217 decadence of taste and the intrusion of the commercial spirit into literature', the

218 overvaluing of a cult of the individual and their mannerisms at the expense of the

219 significant messages of history. ${ }^{23}$ This cult of the individual helped created a celebrity

220 culture built out of 'an extensive, industrialised, and intertextual mode of gossip' in

221 which the details of lives stand for substantive achievement. ${ }^{24}$ Depending on your point

222 of view the anecdotal is a solution to the opportunities and challenges of a new order, or

223 the symptom of the inherent corruption of that order, or both.

224 This then provides the context for Wolcot's exploration of the problems of finding

225 an appropriate discourse of memorialisation in an age whose values are increasingly

226 divorced from the traditional modes of valorisation and in which those responsible for

227 that memorialisation are making a living out of their work. As such, Wolcot's satire

228 engages in this important eighteenth-century debate about the means of reconciling

229 heroism and sensibility, the private and the public, the place of celebrity, and the most

230 appropriate way of establishing, what Jones terms 'a discursive mode capable of ensuring

231 the legibility of character' in an age of politeness and commerce. ${ }^{25}$ It is now appropriate 
232 to turn to some examples of the way in which Wolcot's interest in the nature of biography

233 and the business of its literary representation is aligned with key eighteenth-century

234 historiographical discourses and debates about the meaning and representation of the

235 great figures of history.

237 II. "The Charming Haberdasher of Small Wares": James Boswell and the

238 Anecdotal Method

239 The Epistle to Boswell and Bozzy and Piozzi were both exceptionally popular, the latter

240 going through ten editions in two years. They also had considerable longevity, appearing

241 alongside The Lousiad, as representative of Wolcot's work in Richard Griffin's The

242 British Satirist, Comprising the Best Satires of the most Celebrated Poets from Pope to

243 Byron (1826). They date from an important point in Wolcot's career. In 1782 he had

244 announced Peter Pindar's existence with his Lyrical Odes to the Royal Academicians and

245 in 1785 produced the first canto of the Lousiad, another four cantos of which would

246 appear over the next ten years. The Lyrical Odes (and its sequels) offer a demolition of

247 the pretensions of the Royal Academy's annual exhibition in which all but Sir Joshua

248 Reynolds come in for blunt abuse. The Lousiad is a broad attack on George III as an

249 oafish fool and domestic tyrant. The Boswell satires mark a turn towards a more specific

250 analysis of the relationship between poetry and power, and the poetic representation of

251 men of stature. They represent a satiric attack on the absurdity of biographies of Johnson

252 that focussed on the anecdotal and quotidian, and they seek to connect this to a broader

253 cultural interest in the inane and trivial most obviously articulated in the figure of George

254 III himself. Thus they inaugurate one of Peter's favourite topics in king-baiting - 
255 George's childish love of obscure or worthless detail - and one of his favourite ways of

256 exploring it, the consideration of the proper object of poetry.

257 As is well known, Johnson's death in December 1784 inaugurated a frenzy of

258 speculation, planning and competition over the question of a biography of the great man.

259 In the event Boswell was first out of the blocks with his Journal of a Tour to the

260 Hebrides in September 1785, a revised edition of which appeared before the year was

261 out. Hester Piozzi’s Anecdotes of the Late Samuel Johnson LL.D. was published in March

262 1786. Sir John Hawkins's Life of Samuel Johnson, LL.D would appear in March 1787

263 though he, as Johnson's official biographer, was known to be working on it well in

264 advance (as Peter's satires demonstrate). ${ }^{26}$ Peter's Congratulatory Epistle appeared in

265 February 1786, in response to the revisions to the second edition of Boswell's Journal,

266 and Bozzy and Piozzi the following month in immediate response to the first edition of

267 Piozzi's Anecdotes. As Helen Deutsch's praise for Wolcot as 'perhaps the most brilliant

268 of the many contemporary critics of Boswell's penchant for anecdotes' reveals, these two

269 poems were not unique in addressing the vogue for unflatteringly anecdotal accounts of

270 Johnson. ${ }^{27}$ Indeed Robert Vales records four other occasions upon which Wolcot himself

271 makes reference to Boswell's addiction to anecdote, including one in his notorious "Ode

272 to Lord Lonsdale" of 1792. ${ }^{28}$ The Congratulatory Epistle and Bozzy and Piozzi are

273 however Peter's most sustained meditations on the subject.

274 Bozzy and Piozzi imagines the would-be memoirists Boswell and Piozzi locked in

275 competition over the right to publish the first biography of Johnson. This takes the form

276 of a debate over the relative merits of their previously published Journal and Anecdotes

277 adjudicated by Johnson's friend and executor, the magistrate Sir John Hawkins. The 
278 poem opens with the consternation felt at the news of the death of Johnson amongst the

279 Olympians:

280 Minerva sighing for her fav'rite son,

281 Pronounc'd, with lengthen'd face the world undone:

282 Her owl too, hooted in so loud a style,

283 That people might have heard the bird, a mile:

284 Jove wip'd his eyes so red, and told his wife

285 He ne'er made Johnson's equal, in his life;

286 And that 'twould be a long time first, if ever,

287 His art could form a fellow half so clever. ${ }^{29}$

288 In the midst of what Peter terms the 'Johnso-mania', Boswell and Piozzi emerge as chief

289 amongst the 'pigmy planets' who 'catch their little lustre from the sun' of Johnson's life

290 and opinions. Vying for what Peter calls 'the palm of anecdote' they come before

291 Hawkins:

$292[\ldots]$ for vict'ry, both as keen,

293 As for a tott'ring bishoprick, a Dean,

294 Or patriot Burke, for giving glorious bastings

295 To that intolerable fellow Hastings. (p.9)

296 This introduction is characteristic of Peter's style with its debunking informality and a

297 general facetiousness deployed in an indiscriminate manner. So Edmund Burke's

298 agitations against Warren Hastings over his conduct of the Maratha War that had begun

299 early that year (and would of course culminate two years later with his four-day long

300 opening speech at Hastings' impeachment) are reduced to the stuff of schoolboy banter or 
301 common room snobbery ('glorious bastings', 'intolerable fellow'). Beyond that, the

302 mock-heroic representation of 'Johnso-mania' implicates Peter as part of a cultural

303 discourse that is unable to observe notions of literary decorum and congruity. Peter's

304 voice is comically bathetic as he pursues his satiric target, but the cost of this method is

305 the undercutting of the sense of grandeur of its subject matter in just the ways that it will

306 accuse Boswell and Piozzi in due course. In other words, we assume that it matters

307 whether or not Hastings's actions threatened British interests and influence in India and

308 that, to the anti-ministerial Wolcot, Burke represents a force for good in bringing

309 malpractice to light. In which case Hastings is more than merely 'intolerable' and the

310 facetiousness implied in 'glorious bastings' misplaced. Peter's desire to be funny at all

311 costs compromises his ability to offer a voice of Juvenalian righteous indignation.

312 Hawkins instructs Boswell and Piozzi to trade stories about Johnson from their

313 Journal and Anecdotes respectively so as to determine who should earn the right to a full

314 biography. This functions as a convenient trigger, yet the reader is given no justification

315 for this method of arbitration and no sense of the basis upon which Hawkins will form an

316 opinion about Boswell and Piozzi's relative merits via the anecdotes they relate (what, in

317 this context, does good look like?). The formlessness of the event is reinforced by the fact

318 that Boswell and Piozzi do not engage in debate, rebut or reinforce, rather they talk past

319 each other, refuse to acknowledge the other's presence and instead bombard Hawkins

320 (and the reader) with unconnected anecdotes. One effect of this lack of discursive or

321 argumentative structure - which is the anecdotal method in its purest form of course - is

322 that the reader is encouraged to seek other patterns and make other senses. That being so,

323 what emerges, in a vestigial echo of the previously dominant notion of the anecdote as 
324 complicit in the revealing of the secret (or unofficial or private) histories that offer

325 unflattering insights into the human frailties elided by more anodyne and public accounts,

326 is the impression that all the stories told show Johnson up in a bad light: his irascibility,

327 his gluttony, his desire to be funny or clever or have the last word. Each individual

328 anecdote is footnoted with a page reference within the Journal or Anecdotes at which the

329 original can be found. This cod-apparatus gives the debate the impression of rigour, and

330 anchors the dispute in reality by reassuring the (perhaps presumed to be incredulous)

331 reader that these are authentically from the texts in question. In fact this editorial joke

332 cuts two ways. On the one hand, the reader who goes back to the source texts to look up

333 these passages can join in the fun at Boswell and Piozzi's expense, satirically rereading

334 the passage in the light of what they know Peter has made of it, reading through Peter's

335 eyes as it were. On the other, there is a suspicious of a further neo-Scriblerian joke at the

336 expense of Peter himself and his overly serious-minded assumption that readers are going

337 to be interested (or be taking matters seriously enough) to go to the trouble of looking up 338 references.

339 The poem is punctuated with an interlude during which Hawkins takes a nap. In

340 fine epic style the ghost of 'the surly RAMBLER', appears to him in a dream, implores

341 him to stop Boswell and Piozzi writing their biographies ('nor crucify, through

342 biography, a friend' as Johnson puts it), and leaves after delivering a short speech on the

343 subject of none other than Peter Pindar:

344 Tell PETER PINDAR, should you chance to meet him,

345 I like his GENIUS---should be glad to greet him ---

$346 \quad$ Yet let him know, CROWN'D HEADS are sacred things, 
And bid him rev'rence more, the BEST OF KINGS; (p.27)

348 This comically double-edged meta-textual moment (being told by a visitor from the

349 beyond that he is looking forward to meeting you is not comforting), is made more

350 farcical by a footnote in which Peter expresses puzzlement with this last couplet, given

351 what Peter understands Johnson's view to have been of a 'certain GREAT

352 PERSONAGE'. The levels of recursive, mediated representation at this moment are

353 playful in the extreme, an example of what Kyle Grimes means when he characterises

354 Romantic parodic satire as 'a dialogising counter-movement to the implicit truth-claims

355 of all monological discourses. ${ }^{30}$ In this instance Wolcot has his imaginary author (Peter)

356 evoke via a highly self-conscious epic trope a literary representation of a real but dead

357 person (Johnson), and then has that imaginary author argue with what a figment of his

358 own imaginary imagination has to say. As with most meta-textual jokes it is less amusing

359 spelt out than experienced, but the larger point about the inherent fallacy of biographical

360 attempts to establish a single version of the messy complexity that goes to make up the

361 lives and opinions of their subjects is well taken.

362 Hawkins awakes and the action resumes, but with some differences. By now,

363 Boswell's stories have become entirely self-reflexive, and finally the protagonists round

364 on each other, each attacking the other's desire to scratch what Boswell terms the

365 'anecdotic itch'. They criticise each other's respective anecdotes for their triviality, their

366 inaccuracy, the fact that they are unflattering to Johnson; and they are finally reduced to

367 abusing the size and quality of each other's readerships. At this point Hawkins calls a halt

368 and a plague on both their houses:

369 For shame! For shame! For heaven's sake pray be quiet --- 
Not Billingsgate exhibits such a riot.

Behold for scandal, you have made a feast,

And turn your idol, Johnson to a beast:

'Tis plain the tales of ghosts are arrant lies,

Or instantaneously, would Johnson's rise:

Make you both eat your paragraphs so evil ---

And for your treatment of him, play the devil. (pp.50-51)

377 Hawkins goes on in similar style, though his defence of Johnson is significantly undercut

378 when at the end of the poem he departs to write his own anecdotal biography. Hawkins'

379 biographical ambitions were of course known about even if the content of his offering

380 was as yet unrevealed. Peter suggests that this episode will have inspired Hawkins 'on

381 anecdote to cram' in order to 'vomit first, a life of surly Sam'. The disease of the British

382 biographers is apparently contagious and a symptom of a society that would appear to

383 have lost a vocabulary of the glorious, a way of articulating the profound and timeless.

384 We see explicitly the extent of Hawkins' infection, while in more subtle ways Peter

385 himself runs the risk of being accused of the elevation of the trivial and pettifogging

386 through his memorialisation of it in mock-classical style, complete with footnotes.

387 The Epistle of a month earlier addressed to Boswell alone has a more

388 straightforward rhetorical thrust: the ironic praise of Boswell and an encouragement to

389 him both to hold his nerve in the face of the criticism provoked by his Journal (and

390 revisions to the second edition suggested some such loss of nerve), and to beat Hawkins

391 and Piozzi to producing a full biography of Johnson. Yet whereas Bozzy and Piozzi

392 would only hint at the broader issues of literary taste at stake when abusing each other's 
393 readerships, the Epistle engages in an explicit critique of the cultural malaise whereby the

394 great and the good are trivialised within a popular culture hungry for trivia and anecdote.

395 In doing so he also makes explicit links between the questions of the lowest-common-

396 denominator priorities of cheap print, the celebrity culture it embraces, the recalibration

397 of what counts as history this might involve, and between all this and the figure of

398 George III.

399 Peter widens and deepens his attack on contemporary print culture and its

400 commercial imperatives in the terms of his encouragement to Boswell to keep the faith in

401 the face of the outcry provoked by the first edition of the Journal:

402 Though Wilkes abuse thy brain, that airy mill,

$403 \quad$ And swear poor Johnson murther'd by thy quill;

404 What's that to thee? Why let the victim bleed ---

405 Thy end is answer'd, if the Nation read. (p.16)

406 Peter's mock-messianic invocation of the full biography had already forced home the

407 point that satisfying the public appetite for scurrilous gossip is the best way of achieving

408 longevity for a biography:

409 O Bozzy, still, thy tell-tale plan pursue:

410 The world is wond'rous fond of something new;

411 And, let but Scandal's breath embalm the page,

412 It lives a welcome guest from age to age. (p.14)

413 This is the most striking example of what Deutsch notes as Peter's habit of 'continually

414 evok[ing] [the] past as future spectacle', and as Peter elaborates on that 'something new',

415 he makes clear that it is not the stuff of conventional history: 
Find when he eat and drank, and cough'd, and sneez'd -

Let all his motions in thy book be squeez'd:

On tales however strange, impose thy claw;

Yes, let thy amber lick up e'vry straw:

Sam's nods, and winks, and laughs, will form a treat;

For all that breathes of Johnson must be great! (p.19) ${ }^{31}$

422 Johnson is a victim several times over here of the creation of what, following Richard

423 Schickel, is today understood as 'the illusion of intimacy' at the heart of celebrity. ${ }^{32}$ The

424 details of his personal life, his tics and habits, are paraded for the edification of the

425 reading masses and the profit and fame of the biographer. At the same time it is hard for

426 the reader not to feel some resentment towards Johnson himself as the minutiae of his life

427 are assumed to be of interest and imposed upon the reader.

428 The upshot of the successful pursuit of 'something new' is, says Peter, nothing

429 less than the recalibration of the pantheon of great historians, as he explicitly links the

430 question of anecdotal biography to writing of other sorts of history writing, and indeed

431 other forms of story-telling:

432 Stewart and Robertson, from thee, shall learn,

433 The simple charms of Hist'ry to discern:

434 To thee, fair Hist'ry's palm, shall Livy yield,

$435 \quad$ And Tacitus, to Bozzy, leave the field!

436 Joe Miller's self, whose page such fun, provokes,

437 Shall quit his shroud, to grin at Bozzy's jokes!

438 How are we all with rapture touch'd, to see 
Where, when, and at what hour, you swallow'd tea!

$440 \quad$ How, once, to grace this Asiatic treat,

441 Came haddocks, which the Rambler could not eat. ${ }^{33}$

442 Boswell's achievements and methods overshadow the classical historiography of Livy

443 and Tacitus and the Scottish Enlightenment historiographical and sociological thinking of

444 William Robertson and Dugald Stewart, not to mention the achievements of Joseph

445 Miller (1684-1738), the comedy actor immortalised by John Mottley in his joke book Joe

446 Miller's Jests, or the Wit's Vade-Mecum of 1739. On one level this is facetious

447 hyperbole and an example of ambitiously extended zeugma as Bozzy's performance

448 simultaneously overtops that of Livy, Tacitus and the most famous joke-teller of the age.

449 But on another it is worrying at a problem within eighteenth-century historiography

450 discussed in section one, namely that a view of history as the representation of active

451 political virtue is being overtaken by a sociable, sentimental ideology whose implications

452 for the writing of history had yet to unfold but whose potentially levelling implications

453 were clear. As Phillips puts it, if it was 'increasingly hard to think of history as

454 exclusively concerned with the narrative of political action' then the editorial task of the

455 historian was suddenly increased beyond measure. ${ }^{34}$ The same cultural moment has been

456 observed in the narrowing of the distance between biography and history to the point

457 where in the words of Grossman, 'history itself came to resemble a kind of national

458 biography. ${ }^{35}$ At the same time, according to Peter here with his references to Livy and

459 Miller, History has become a joke, or at least indistinguishable from it.

460 It is notable that all these comments throw an emphasis upon Boswell's profile as 461 an author, rather than on the subject his efforts should illuminate. In Bozzi and Piozzi 
462 Boswell is variously described as a 'mighty shark for anecdote and fame'; a 'charming

463 haberdasher of small ware'; an assiduous labourer 'amid the anecdotic mine'; a 'lively,

464 bouncing cracker' at the tail of Johnson's comet; and 'a very Laz'rus at the rich man's

465 table'. Peter even describes Boswell as a 'watchful cat' who for 20 years 'did'st mousing

466 sit before Sam's mouth so wide, | To catch as many scraps as [he] was able'. In the

467 Epistle, the emphasis on acquisition, on the gathering of scraps, hunting and mining,

468 places the memoirist front and centre, his activity distracting attention from the supposed

469 subject of the work. This is not the kind of memoir Disraeli would have in mind a few

470 years later, with its emphasis not on the collection of anecdote but upon their disposal

471 into a form that allowed the allusion that the reader was creating the narrative. Small

472 wonder perhaps then that at the end of his Dissertation he would expressed a desire for a

473 native anecdotalist to rival the French masters of the mode, one who combines the

474 'learning' of Joseph Warton, the 'taste' of Horace Walpole and the 'faithfulness' of

475 Boswell, where faithfulness might mean both loyalty to subject and to the task of

476 revealing all.

477 Wolcot may be responding satirically to pressures and movements within

478 historiographical writing that were felt by contemporaries to do with the editorial shaping

479 and selection of a richer history of people, characters and the times, but he also has a

480 particular figurehead for this cultural obsession with the trivial in the Epistle. Peter's

481 claim that 'pleas'd, on thy book thy sovereign's eye-balls roll, | Who loves a gossip's

482 story from his soul' introduces a lengthy (over thirty line) account of the 'one huge

483 cyclopedia of wit' that makes up the King's brain. In what would become the familiar

484 shape of his satires on George III, Peter emphasises the utmost triviality or mundane 
485 practicality of almost everything the King knows, generating his comic charge from the

486 discrepancy between the power of majesty and ludicrous banality or penny-pinching

487 economy of most of the things he concerns himself with:

488 Which gard'ner hath most cabbages and peas,

489 And which old woman hath most hives of bees;

490 Which farmer boasts the most prolific sows,

491 Cocks, hens, geese, turkies, goats, sheep, bulls, and cows; (pp.10-11)

492 In later satires on George's husbandry (notably The Royal Tour; or Weymouth

493 Amusements), these preoccupations are integral to Peter's attack on the King's ill-placed

494 parsimoniousness; ill-placed, according to Peter, because the King's much trumpeted

495 frugality is often sharp-practice at the expense of the livelihoods of his own subjects. In

496 the Epistle they work to link Boswell's idea of a biography of a great man, and his sense

497 of the reading public's appetite for the inane or grubby details of such biographies, with

498 what passes for intellectual prowess with the sovereign. Both suggest a culture drowning

499 in a sea of inconsequential nonsense, of triviality and distasteful gossip.

500 The references to George III are then the most significant of several moves that

501 allow the Epistle to build from an attack on the impertinence of one man seeking to hitch

502 his star to the fame of a literary great to the identification of a more widespread cultural

503 malaise. One of the ironies of this is that Peter's argument is fundamentally anecdotal,

504 relying on taking the singular (Boswell's biographical activities) as representative of the

505 whole (a cultural taste for gossip). This shadows the larger question these two poems

506 repeatedly raise about the place of Peter himself within this critique, since the sheer

507 pyrotechnical brilliance and fascinated exuberance of his depiction of the "charming 
508 haberdasher of small wares' threatens to collapse the distinction between Peter and the

509 world he describes. If Boswell's celebrity relies on Johnson, then Peter's relies on

510 Boswell relying on Johnson. It is a deeply compromised position. More generally, the

511 culture of cheap print, the same culture that would soon be able to facilitate the

512 production of forty two and a half thousand copies of Peter's own works (though Peter's

513 print did not in fact come cheap), encourages the peddling of this mind numbing trivia. ${ }^{36}$

514 The cult of celebrity and personality, the same cult of celebrity and personality that has

515 people rush to enjoy the picaresque literary adventures and opinions of Peter in print,

516 fosters, according to Peter, an attitude in which admiration for greatness can only be

517 expressed perversely via an obsession with the intimate details of everyday habits. In this

518 way Peter is a part of the malady he diagnoses, creating and satisfying the appetite his

519 poems otherwise condemn. He is in these poems an example of the dynamic whereby

520 'even writers who lamented the degradation of literature and thought themselves as rising

521 above it, often became embroiled, willingly or unwillingly, in the culture of

522 commercialised celebrity. ${ }^{37}$ In the next section I want to turn to some of Wolcot's further

523 examinations of the relationship between writer and subject, and the problems of being a

524 public writer in a period where virtue has been replaced by celebrity and where it feels

525 like there is no longer a relevant public language of praise.

527 II. "Tribute All Sincere": Brother Peter, Brother Tom, and the Poetic Discourse of 528 Majesty.

529 The Boswell poems outline a problem caused by a mismatch between a figure of great 530 stature in the world of letters - Johnson - and the ways in which popular culture would 
531 seem to seek to memorialise figures of stature via the anecdotal and the 'tell all' memoir.

532 It is as if the discourse of memorialisation has come adrift from the characteristics,

533 actions and behaviours traditionally considered worth memorialising. The Warton poems

534 suggest a similar but opposite mismatch, this time between a traditional discourse of

535 royal eulogy and a royal figure whose behaviours and values are more in tune with the

536 cultural values so lamented in the Boswell poems.

537 Thomas Warton was appointed Poet Laureate in 1785, and his output in this office

538 was subject to immediate and widespread derision in, for example, a collection of

539 Probationary Odes for the Laureateship of the same year. ${ }^{38}$ Peter weighed in on three

540 occasions in 1787 (Ode Upon Ode; Instructions to a Celebrated Laureat [...] alias Mr

541 Whitbread's Brewhouse; Apologetic Postscript to Ode Upon Ode) and again in 1788 with

542 Brother Peter to Brother Tom. The inconvenience of Warton's death in 1790 did not

543 curtail Peter's interest in the subject: his Advice to the Future Laureat: An Ode (1790)

544 laid out the poetic qualifications for filling the recently vacated post, while the subtitle to

545 one of his most famous poems, The Royal Tour and Weymouth Amusements: A Solemn

546 and Reprimanding Epistle to the Laureat (1795) makes clear that it is occasioned by

547 Peter's disapproval of the then incumbent Henry James Pye. In the meantime Peter also

548 offered various other animadversions on his relationship with the King and, by extension,

549 the relationship between poets and majesty.

550 The 'advice to the poet' ploy serves of course as a useful disclaimer that allows

551 Wolcot to claim that Peter is not attacking the King, but rather those who write about

552 him. Nevertheless it provides other satiric opportunities. In the case of the Warton poems

553 the examination of the relationship between the poet (and the notion of poetic merit) and 
554 the subject matter at hand is a means of satirising the whole business of state-sponsored

555 verse and through this the person of the King. It also provides an opportunity to explore,

556 through the fictional poet Peter, the question of what kind of poet can be envisaged as

557 flourishing in this culture, and beyond that it was an established method through which

558 writers signalled a self-conscious interest in the writing of history. As Noelle Gallagher

559 has most recently demonstrated, satirists from the Restoration onwards used the Advice

560 to the Artist genre to 'situate their works within an English historiographical tradition'

561 and make 'historical representation itself a central issue in the portrayal of past persons

562 and events' in such a way as to suggest, in a position becoming familiar in this article,

563 that 'history might be less comprehensible from a lofty vista than from beneath the

564 narrowing lens of a microscope'. ${ }^{39}$ Wolcot's own position is of course tending in the

565 other direction in terms of its conclusions, focussing on the potentially negative

566 consequences of the 'narrowing lens.' Yet it is important to be alert to the fact that he is

567 working within a recognised tradition, albeit coming to a different conclusion than many

568 that had come before, since it is another example of a way in which Wolcot's

569 preoccupations can be seen within the context of a larger historiographical and

570 intellectual framework.

571 Given Wolcot's interest in the ways in which Johnson might be memorialised for

572 the 1780s, it is hardly surprising that he had Peter engage in conversation with Warton,

573 since Warton in effect raises the same question when he favourably compares George,

574 and the sorts of poems it is fitting to write about him, with poems written in praise of

575 great men from the past. In effect Warton calls attention to the tensions discussed in

576 section one of this article; what Adam Potkay has termed 'a cultural seam between two 
577 ethical domains' represented by the ‘sublime eloquence and political community' of

578 antique civic virtue and that of the 'subdued manners in private life' seen on as

579 essentially modern and polite. ${ }^{40}$ In his Ode on His Majesty's Birth-day, June 41787

580 Warton considers the royal myth-making of Chaucer, Spenser and Dryden on behalf of

581 previous monarchs, before concluding:

582 Had these blest Bards been call'd, to pay

583 The vows of this auspicious day,

$584 \quad$ Each had confess'd a fairer throne,

585 A mightier sovereign than his own!

$586 \quad$ Chaucer had bade his hero-monarch yield

$587 \quad$ The martial fame of Cressy's well-fought field

588 To peaceful prowess, and the conquests calm,

589 That braid the sceptre with the patriot's palm:

590 His chaplets of fantastic bloom,

591 His colourings, warm from Fiction's loom,

592 Spenser had cast in scorn away,

593 And deck'd with truth alone the lay;

$594 \quad$ All real here, the bard had seen

595 The glories of his pictur'd Queen!

596 The tuneful Dryden had not flatter'd here,

$597 \quad$ His lyre had blameless been, his tribute all sincere! ${ }^{41}$

598 In Warton's eyes valuing George III above Edward III involves valuing a different set of

599 arts and practices, a set more suitable for the modern, polished world. It is a distinction 
600 lost on Peter, whose response in the Instructions to the 'laurell'd ODE-MAN' is blunt

601 ('smoking' in this context has the - already - archaic meaning of 'ridicule' or 'make fun

602 of'):

603 But, Thomas Warton, without joking,

$604 \quad$ Art thou, or art thou not, thy Sov'reign smoking?

605

$606 \quad$ How can'st thou seriously declare

607

That George the Third

608 With Cressy’s Edward can compare,

609 Or Harry?----'tis too bad, upon my word. ${ }^{42}$

610

611 In his early Ode for the New Year, 1787 Warton had in similar vein compared the 'rough

612 magnificence' and military adventuring of the Crusades with the 'worthier triumphs' of

613 Georgian England and its commitment to the values of 'commerce, peace and art'. The

614 opening section of Peter's Ode upon Ode paraphrases this position in a way that

615 highlights the difficulty of the poet whose frame of reference is caught between a world

616 of ancient eloquence and modern commercial politeness:

617 Great (says the Laureat) were the Poet's puffings,

618 On idle daring red-cross ragamuffins,

619 Who, for their childishness, deserved the birch:

620 Quoth Tom, a worthier subject now, thank God!

621 Inspires the lofty Dealer in the Ode,

622 Than blockheads battling for old Mother-Church. 
624 Times (quoth our courtly bard) are alter'd quite;

625 The poet scorns what charm'd of yore the fight;

626 Goths, vandals, castles, horses, mares:

627 The polish'd poet of the present day

628 Doth in his tasty shop display,

629 Ah! vastly prettier-colour'd wares. ${ }^{43}$

631 Peter's characterisation of crusaders as 'red-cross ragamuffins' is a reductio ad absurdum

632 of Warton's position. It highlights the contradiction between Warton's platitudinous way

633 of writing about the past and the attitude he displays towards it when he dismisses it as

634 anachronistic. In effect Peter takes Warton at his word and in doing so shows Warton as

635 caught in a rhetorical trap of his own devising. Similarly, Peter's stanzas are animated by

636 a tension between two different rhetorical registers: on the one hand 'courtly bard' and

637 'polish'd poet' and on the other the notion of the poet as a shopkeeper displaying his

638 goods. This tension between the commercial and the civic is best encapsulated in the

639 phrase 'lofty Dealer in the Ode'. Peter's critique of Warton thus aims to demonstrate the

640 mis-match between the business of poetry and royalty, or at least its current embodiment.

641 Here and elsewhere Peter sees Warton's mistake in part as one of misunderstanding the

642 kind of poetry fit for the court of George III. If the values of the Georgian world are

643 different from those of his warrior-prince forebears, then there needs to be a different sort

644 of poetry and language, one that seems beyond Warton's grasp or imagining. 
This dilemma about the appropriate memorialisation of the particular interests and

646 achievements of George III is the context for the substantial matter of Instructions to a

647 Celebrated Laureate. It is an extended anecdote about the royal birthday treat of 1787, a

648 visit to Whitbread's Brewery aimed at satisfying royal curiosity as to the art of brewing.

649 Such sustained anecdotes would come to serve Peter well in his satires of George and,

650 according to John Barrell, were 'by 1795 much more corrosive of the King's majesty

651 than [...] Gillray's caricature' ${ }^{44}$ Peter presents this mock-epic account of the visit to

652 Warton as a model for the appropriate expression of the qualities of the King in verse.

653 Furthermore Peter offers himself as the poet best placed to match form and theme,

654 language and subject. That said, and from the very start of the poem when Peter ascribes

655 its epigraph 'sic transit gloria mundi' to 'old sun dials' rather than any more elevated

656 source, the reader is clear that this is a distinctly double-edged compliment. More sharply

657 than in the Boswell poems, Wolcot has Peter act both as indicter and indictment of the

658 discourse of triviality he attacks. In the former, Boswell and Piozzi are 'pigmy planets'

659 who 'catch their little lustre from the sun' of Johnson. In the latter, there is no such

660 incongruity between George and Peter because Peter's poetry of the inconsequential

661 matches the character, actions and nature of the King and times. Whereas Boswell and

662 Piozzi had presumed on the reputation of the great Johnson with their mundane tittle-

663 tattle, Peter's jokey, colloquial informality, his fundamentally bathetic turn, resonates

664 absolutely with the 'microscopic genius' of George in a way that the solemn platitudes of

665 Warton had not.

666 The King's qualities can be summarised as stupidity, rudeness and selfishness.

667 His stupidity comes in the apparently indiscriminate inanity of his interest in brewing: 
And now his curious Majesty did stoop

To count the nails on ev'ry hoop:

673 George's enquiries into 'the world of small' are inexhaustible. His numb-skull curiosity

674 on every matter must be satisfied however reductive and missing of the overall point. It

675 culminates in a moment that combines closely-observed social comedy and broad farce,

676 when Whitbread tells the royal party that if he laid all his barrels side by side in a row

677 they would reach Kew. George's response to this commonplace way of indicating the

678 large number of barrels Whitbread has in his possession demonstrates a literal minded

679 curiosity devoid of any effort to really engage with what he is being told:

680 "What? If they reach to Kew then, side by side,

$681 \quad$ What would they do plac'd end to end?"

682 To whom, with knitted calculating brow,

683 The Man of Beer most solemnly did vow,

684 Almost to Windsor that they would extend;

685 On which the King, with wond'ring mien,

686 Repeated it unto the wond'ring Queen:

688 On which, quick turning round his halter'd head;

689 The brewer's horse with face astonish'd neigh'd:

690 The brewer's dog too pour'd a note of thunder, 
Rattled his chain, and wagg'd his tail for wonder. (p.16)

692 This emphasis on child-like literal-mindedness, while not supportive of George's dignity

693 has nevertheless been interpreted by Vincent Carretta as part of Wolcot's 'laughing

694 treatment of the King' - whom he finds 'embarrassing' rather than anything stronger -

695 within an overall 'rhetoric of disappointment, not disobedience' that stretches as far back

696 as Andrew Marvell. ${ }^{45}$ The 'Peter Pindarian tone', according to Carretta, 'reveals no

697 serious discontent with the rule of George III' and indeed renders George harmless and

698 protects him from more searching political critique. ${ }^{46}$ A similar point has been made by

699 Carol Percy in her consideration of the ways in which George's supposedly idiosyncratic

700 form of speech was rendered. It may have opened George up to a degree of ridicule, but

701 more profoundly it 'helped to craft his more public image as an ordinary man, able to

702 bridge the social gulfs mapped by linguistic difference. ${ }^{, 47}$ By contrast however, John

703 Barrell has reinvested the satires of the 1790s (poems such as A Royal Tour) with a more

704 pointed political meaning by interpreting them as an attack on George III's particular

705 brand of royal ideology of ordinariness and 'the irreconcilable desires of the King and

706 crowd alike for a monarch both majestic and familiar. ${ }^{, 48}$ Barrell does this by way of a

707 comparison with what he sees as less purposeful efforts in the 1780s. However, it is

708 possible to see the latent (and not so latent) viciousness of the later portraits of the King

709 in these earlier efforts, and a similar focus on the image of ordinariness as an image, and

710 a hypocritical one at that. This is apparent in what Peter depicts as George's habit of

711 asking multiple, indiscriminate questions:

712 Now Whitbread inward said, "May I be curst

713 If I know what to answer first”. 
714

715

716

717

718

719

720

721

722 factness:

723

724

725

726

727

728

729

730

731

732

733

734 authority presumes familiarity while not submitting itself to the rules that govern

735 interactions between the genuinely equal. Carretta suggests that the 'domestication of the

736 regal image brought the viewer up to the King's level as much as it brought the king 
737 down to his subjects', but the most significant point within these interactions is the

738 double-standard and hypocrisy that sits at the heart of this supposed ordinariness and

739 apparent parity.

740 George's questions appear trivial and random, but an interest in penny-pinching

741 runs through them. This is most marked when the King 'noteth notable things':

742 Mem.--- 'Tis hops that give a bitterness to beer ---

743 Hops grow in Kent, says Whitbread, and elsewhere.

Quaere.---Is there no cheaper stuff? Where doth it dwell----

$746 \quad$ Would not horse aloes bitter it as well?

747

748

Mem.---To try it soon on our small beer-----

749

'Twill save us sev'ral pounds a year.

750

751

752

Mem. ---To remember to forget to ask

Old Whitbread to my house one day ----

753

754

Mem.----Not to forget to take of beer the cask

755 The brewer offer'd me, away. (p.17)

756 The King makes his notes in 'a very pretty memorandum book, With gilded leaves of

757 asses skin so white', reinforcing the hypocrisy of the penny-pinching. Equally the

758 laughter generated by the last quatrain, with its opposing impulses (though congruent

759 sentiments) united through rhyme scheme, feels more hollow later in the poem when the 
760 royal family greedily tuck into the lunch offered by the Whitbreads, a mock-epic

761 decimation 'Of flesh, and fish, and fowl of ev'ry nation.'

762 At the end of the anecdote Warton reproaches Peter with the question "[i]s this an

763 action, Peter? this a deed | To raise a Monarch to the sky?”. In effect Warton voices

764 Peter's own critique of Boswell and Piozzi's memorialisation of Johnson via unflattering

765 anecdote in the earlier poems. However Peter is unrepentant, refusing to concede that

766 this is an unacceptable way of celebrating George's unique talents:

767 But this I tell thee, Thomas, for a fact,

768 Thy Caesar never did an act

769 More wise, more glorious, in his life.

770 Now GOD preserve all wonder-hunting KINGS,

771 Whether at Windsor, Buckingham, or Kew house,

$772 \quad$ And may they never do more foolish things

773 Than visiting SAM WHITBREAD and his brewhouse. (p.27)

774 The activation of the more conventional rhetoric of royal paean- the honorific Caesar, the

775 references to wisdom and glory - reminds the reader again of the questions of political

776 virtue and the representations of political virtue raised by Warton and applied literally for

777 satiric effect by Peter. Equally it shows Peter to be no nostalgic apologist for a previous

778 model of political virtue, for all that his satire attacks the modern notions of manners and

779 social virtue that have evacuated grandeur and meaning from high office. George is

780 recuperated by Peter giving thanks for a King about whom this is the worst that can be

781 said, an observation that perforce brings to mind all the much more unpleasant things 
782 monarchs are capable of doing. It may be an act of royal recuperation, but it is one that

783 comes with the strength of a threat.

784 In all this Peter is of course assuming a position from which he can judge George.

785 Wolcot raises the stakes of this insight still further by exploiting the licence of this

786 fundamentally levelling perspective to conceive of the relationship between poet and king

787 in a radically different way. As Peter puts it in Brother Peter to Brother Tom:

788 The world may call me liar, but sincerely

789 I love him ----for a partner, love him dearly:

790 Whilst his great name is on the ferme, I'm sure

$791 \quad$ My credit with the Public is secure.

792

793

Yes, beef shall grace my spit, and ale shall flow,

As long as it continues George and Co.;

795

That is to say, in plainer metre,

George and Peter. ${ }^{49}$

797 Indeed, Peter can even posit a version of this partnership whereby he is the senior partner.

798 He concludes to dedication to Pye in the Royal Tour by taking matters one step further

799 when he says that he no more hates kings and queens than the hunter hates the wild boar:

$800 \quad$ May KINGS exist---and TRIFLE pig with Kings!

$801 \quad$ The MUSE desireth not more precious things----

$802 \quad$ Such sweet mock-grandeur! —so sublimely garish!

803 Let's have no WASHINGTONS: did such appear,

804 The MUSE and I had ev'ry thing to fear ---- 
Soon forc'd to ask a pittance of the parish.

806

807 Such want not praise---in native virtue strong:

808 Tis folly, folly, feeds the POET'S song. ${ }^{50}$

809 In another context the final line could be a Juvenalian rallying cry to the righteous

810 standard of satire. But Wolcot has too close an eye on the literal reality behind the dead

811 metaphor, and the immediately previous reference to Poor Relief makes the notion of

812 feeding the poet's song entirely inseparable from the imperative of feeding the poet.

813 In laying bare the profit motive in his satire Peter reveals that his commitment to

814 the radical cause to be one of financial expediency rather than principled opposition. Yet

815 to say that Peter portrays the relationship between poet and monarch to be one in which

816 the latter provides opportunities to the commercial advantage of the former is also to say

817 something rather far reaching about Wolcot's disrespect for the monarchy. He has Peter

818 reconfigure kings and queens as, at best, partners in the poet's business, and, at worst, a

819 commodity upon which the professional writer can trade. This might not be a particularly

820 idealistic or appealing way of understanding equality of station, but its grubby logic is all

821 the more deliberately undermining of royal authority for that.

822

\section{III. Conclusion}

824 The poems discussed here explore the literary representation and mediation of

825 'greatness', and suggest its deterioration from the noble Lives model of the ancients to

826 the triviality of celebrity culture either as a response to the demands of a crass

827 commercialism or as a result of the inherent inanity of its modern subject. Yet they also 
828 reveal a fraught and contradictory position for the writer. On the one hand Wolcot

829 laments and satirises the absence of a recognised or applicable rhetoric of greatness: there

830 is no way of doing justice to Johnson, and no way but Peter's of doing justice to George.

831 Yet on the other hand he lambasts the hypocritical high-handedness of the representatives

832 of the political order who would be the beneficiaries of that rhetoric of greatness and who

833 Wolcot might otherwise be thought of as defending though this attack on the trivial

834 levelling of modern culture. Wolcot's ultimate attitude towards Warton is one of pity for

835 being lumbered with George III as a figure around which to attempt to create a model of

836 discourse of royal virtue for the modern world that dispenses with the ludicrous

837 anachronisms of previous royal paean. Peter Pindar is then a way of wrestling with the

838 paradoxes of an age suspicious of, or anxious about, the relevance of traditional ways of

839 mediating greatness yet unable to formulate a coherent or appealing alternative way of

840 articulating a more relevant set of values. Peter on Boswell on Johnson, and Peter on

841 Warton and Peter on George III represent Wolcot's satiric investigation of nature of

842 modern biography as surely as Disraeli on Anecdote offers a discursive one.

843 Peter Pindar emerges as both tenor and vehicle in this process, calling attention to

844 the pitfalls of the age in significant part by embodying them. Any effort to separate John

845 Wolcot and Peter Pindar completely would not only be naïve but fruitless. When, in the

846 first canto of the Lousiad (1785), Peter announces his switch to royal satire with the claim

847 that he 'LOVE and the SONS OF CANVAS quit[s] for Kings' he is collapsing the

848 distinction between the Persian Love Elegies that had appeared in 1773 under Wolcot's

849 name and Peter's own debut attacking the painters of the Royal Academy, the Lyric Odes

850 to the Academicians (1782). But regardless of such elisions, it is crucial to understand 
851 Peter Pindar as other than Wolcot, an unreliable commentator who is as often as not the

852 butt of Wolcot's satire, calling out what Wolcot identifies as the idiocies of his age by as

853 often as not exemplifying them. Distinguishing Peter from John allows for an

854 understanding of Peter as a poetic creation, a character in Wolcot's imaginative world,

855 and the acknowledgement that he is as open to interrogation and indeed satiric

856 representation as any of the figures he is himself satirising. ${ }^{51}$

857 Understanding Wolcot and his creation Peter in such terms not only deepens our

858 sense of Wolcot's sophistication as a poet and satirist but also provides a richer context

859 for understanding the later Wolcot within of the range and subtlety of political responses

860 to the French Revolution in Britain. The last twenty years have seen significant insights

861 into the contexts and complexities, the debates and differentiations in what had

862 previously been interpreted as a neat dichotomy of radical/reactionary. ${ }^{52}$ Of particular

863 importance has been the reconfiguring of the notion of political loyalism (especially in

864 historical studies) not only as a something with many hues but as 'an empowering

865 movement that gave its followers a public presence and political voice with which to

866 criticise the polity they sought to defend. ${ }^{53}$ Yet with a few exceptions the debate about

867 Wolcot has not moved beyond questions of apostasy and double-dealing. Or again, the

868 emphasis on competition between radical and loyalist writers over terms and ideas - what

869 Mori terms 'sites of contest and inspiration' - should open the door on contextualising

870 the practices of Wolcot discussed above in terms of others within the period. For

871 example, the work discussed in this article resembles what Kyle Grimes has termed

872 Romantic 'hacker satire', characterised as 'parasitic, derivative, opportunistic or

873 parodic'. ${ }^{54}$ Grimes' account of William Hone's satiric voice as a 'parodic seizing of 
874 cultural authority' that is 'definable by the role it plays in very immediate and historically

875 specific discursive power struggles' offers a compelling way of revaluing Peter's interest

876 in the local and, in the long view of history, trivial regardless of any judgement about the

877 extent to which they shared a political position across generations. ${ }^{55}$ It also articulates the

878 opportunistic way in which Peter is both a mouthpiece for and a target of Wolcot's

879 various satiric agenda, including the self-conscious and explicit consideration of the

880 complicity between satirist and object of satire. The reader is invited to laugh at Peter

881 almost as often as with him, and sometimes both with and at him at the same time.

882 Equally, to read Wolcot working in this way in the mid-1780s is to offer a

883 contribution to the appreciation of what still seems like a lost decade in eighteenth-

884 century poetry. Even sympathetic readings of Wolcot tend to focus on his output post-

8851789 , and it is notable that many of the ideas and concepts deployed in this essay have

886 had their most thorough and significant articulation in relation to periods either side of

887 the work they are being asked to do here. It is $n^{56}$ otable then to see how Wolcot's poetry

888 from the 1780s combines themes and preoccupations more usually understood in terms of

889 earlier or later periods, but which he demonstrates exist in vital relation through his work.

890 As such the insights generated are important not just for understanding the significance of

891 Wolcot's work during this time, but for arguing for the importance of a decade itself

892 frequently only understood in unflattering comparison with the one that followed.

893 Through Peter Pindar, Wolcot diagnoses and critiques a crisis of cultural authority in his

894 age, creating a spokesman for that crisis who anatomises, exemplifies and glories in its

895 absurdities. Acknowledging this recognition is a further step towards the rehabilitation of 
896 not only one of the most prolific poetic voices of the age, but one of unacknowledged

\footnotetext{
${ }^{1}$ As cited in Benjamin Colbert, "Petrio-Pindarics: John Wolcot and the Romantics". European Romantic Review, 16.3 (2005): 311-328. DOI: 10.1080/10509580500211343, p.312.

${ }^{2}$ Donald Kerr, “'Satire is Bad Trade': Dr John Wolcot and his Publishers and Printers in EighteenthCentury England." Cardiff Corvey: Reading the Romantic Text, 12. Online: Internet (28/09/2010): http://www.cf.ac.uk/encap/corvey/articles/cc12_n02.html. For example 42,500 copies of his 1794 collection Pindariana were printed.

${ }^{3}$ Jeanne Griggs, "Self-Praise and the Ironic Personal Panegyric of Peter Pindar", The Age of Johnson 8 (1997): 223-254, (p.254). See Tom Girtin's Doctor with Two Aunts: A Biography of Peter Pindar (London, 1959) for a sympathetic and now rather venerable, but still the most detailed and serviceable, account of Wolcot's career, life and the growth of these perceptions; and also Robert L Vales, Peter Pindar (John Wolcot) (New York, 1973).

${ }^{4}$ The hitherto most significant reassessments of Wolcot's achievements can be found in Grzegorz Sinko, John Wolcot and his School: A Chapter from the History of English Satire (Warsaw, 1962); Iain McCalman, "John Wolcot" in An Oxford Companion to the Romantic Age: British Culture, 1770-1803. gen. ed. Iain McCalman, (Oxford: Oxford University Press, 1999), pp.765-66; Gary Dyer, British Satire and the Politics of Style, 1789-1832 (Cambridge: Cambridge University Press, 1997), pp.31-7; Colbert, "Petrio-Pindarics"; John Barrell, The Spirit of Despotism: Invasions of Privacy in the 1790s (Oxford: Oxford University Press, 2006), pp.118-144; Noah Herringman, “ "Manlius to Peter Pindar”: Satire, Politics and Masculinity in the 1790s', Romanticism and Patriotism: Nation, Empire, Bodies, Rhetoric, A Romantic Circles Praxis volume, ed. Orrin N.C.Wang (2006) [8 June 2014].

${ }^{5}$ Dyer, British Satire, 3.

${ }^{6}$ Barrell Spirit of Despotism, 138. Other dimensions to Barrell's recuperation of Peter will be discussed below.

${ }^{7}$ See also the works of textual scholarship on Wolcot. There is an edition of Bozzy and Piozzi in John Strachan and Graeme Stone's Parodies of the Romantic Age (London: Pickering and Chatto, 1998) and of The Lousiad in volume 3 of Strachan's British Satire 1785-1840 (2003)

${ }^{8}$ Steven E Jones, 'Introduction' to The Satiric Eye: Forms of Satire in the Romantic Period, ed Steven E Jones, (New York: Palgrave, 2003), p.1. See also his earlier Satire and Romanticism (London, 2000) and Colbert's 'Popular Romanticism: Publishing, Readership and the Making of Literary History' in Authorship, Commerce and the Public: Scenes of Writing, 1750-1850, ed E.J. Clery, Caroline Franklin and Peter Garside, (London: Palgrave, 2002), pp.153-68.

${ }^{9}$ McCalman, "John Wolcot”, p.765

${ }^{10}$ Lionel Grossman, 'Anecdote and History', History and Theory 42.2 (May, 2003), 143-168 (p.154).

${ }^{11}$ Rebecca Bullard, The Politics of Disclosure, 1674-1725: Secret History Narratives (London: Pickering and Chatto, 2009), p. 37, p.11. Her argument that secret history is opposed to arbitrary and absolute government regardless of its political stripe differs from the Whig reading offered for example by Annabel Patterson in Early Modern Liberalism (Cambridge: Cambridge University Press, 1997), pp.183-5.

${ }^{12}$ Johnson, The Adventurer 99 (16 October 1753) in Samuel Johnson, ed Donald Greene, (Oxford: Oxford University Press, 1984), pp.273-77 (p.276)

${ }^{13}$ Mark Salber Phillips, Society and Sentiment: Genres of Historical Writing in Britain, 1740-1820 (Princeton: Princeton UP, 2000), p.17.

${ }^{14}$ Helen Deutsch, Loving Dr Johnson (Chicago: Chicago University Press, 2005), pp.178-9

${ }^{15}$ Samuel Johnson, The Rambler 60 (13-10-1750), in Greene (ed), pp.204-207 (p.205)
} 
${ }^{16}$ Deutsch, Loving Dr Johnson, 9.

${ }^{17}$ A Dissertation on Anecdotes, in Literary Miscellanies, a New Edition, Enhanced (London: John Murray, 1801) p.27. The first edition appeared in 1793.

${ }^{18}$ Disraeli, Dissertation on Anecdotes, p.64.

${ }^{19}$ David Simpson, The Academic Postmodern and the Rule of Literature: A Report on Half Knowledge (Chicago: Univ. Chicago Press, 1995), p.56

${ }^{20}$ J.G.A.Pocock, Virtue, Commerce, History: Essays on Political Thought and History, Chiefly in the Eighteenth Century (Cambridge: Cambridge University Press, 1985), p.122.

${ }^{21}$ Scott, The Edinburgh Review 6 (July, 1805), p.446. See Iain MacDaniel, Adam Ferguson in the Scottish Enlightenment: The Roman Past and Europe's Future (Harvard: Harvard University Press, 2013); John Mullan, Sentiment and Sociability: The Language of Feeling in the Eighteenth Century (Oxford: Oxford University Press, 1988); Dafydd Moore, Enlightenment and Romance in the Poems of Ossian (Aldershot: Ashgate, 2003), pp.87-112.

${ }^{22}$ Robert W. Jones, Literature, Gender and Politics in Britain during the War for America 1770-1785 (Cambridge: Cambridge University Press, 2011).

${ }^{23}$ Grossman, "Anecdote and History”, p.154.

${ }^{24}$ Jason Goldsmith, 'Celebrity and the Spectacle of Nation' in Romanticism and Celebrity Culture, ed Tom Mole (Cambridge: Cambridge University Press, 2009), 21-40, p. 22.

25 Jones, Literature, Gender and Politics, p.31.

${ }^{26}$ See Sir John Hawkins The Life of Samuel Johnson, LL.D., ed O.M.Brack Jnr (Athens, GA, 2009)

${ }^{27}$ Deutsch, Loving Dr Johnson, p.8. For analysis of some of the more eye-watering examples of these see also pp.140-47.

${ }^{28}$ Vales, John Wolcot, pp.42-3. The "Ode to Lonsdale" was an ironic retraction of the previous year's "Commiserating Epistle to James Lowther, Lord Lonsdale" (in response to which Lonsdale had threatened legal action). Unfortunately for Wolcot, it was taken seriously as an act of craven backsliding, most notably by James Gilray in "SATAN in all his Glory" (1792), and became one of the central planks of the charge against Wolcot that he was lacking conviction and moral fibre.

${ }^{29}$ Bozzy and Piozzi, Or, The British Biographers, A Town Ecologue, by Peter Pindar Esq (London: G. Kearsley \& W. Foster, 1786), p.4.

${ }^{30}$ Kyle Grimes, "Verbal Jujitsu: William Hone and the Tactics of Satirical Conflict" in Jones (ed), The Satiric Eye, 173-84, p.181. The phrase 'crown'd heads' is a direct reference, given its subject matter, to The Lousiad, making that another metatextual joke.

${ }^{31}$ Deutsch, Loving Dr Johnson, 9.

${ }^{32}$ See Schickel's seminal Intimate Strangers: The Culture of Celebrity in America (1985/2001). Closer to home, see Cheryl Wanko, "Celebrity Studies in the Long Eighteenth Century: An Interdisciplinary Overview”, Literature Compass 8/6 (2011): 351-362. Doi 10.1111/j.1741-4113.2011.00806.x. See also Claire Brock, The Feminisation of Fame, 1750-1830 (Basingstoke: Palgrave, 2006); Mole (ed)

Romanticism and Celebrity Culture; Frank Donoghue, The Fame Machine: Book Reviewing and Eighteenth-Century Literary Careers (Stanford: Stanford Univ. Press, 1996).

${ }^{33}$ A Poetical and Congratulatory Epistle to James Boswell, Esq. on his Journal of a Tour to the Hebrides with the celebrated Dr Johnson, By Peter Pindar Esq (London: G. Kearsley, 1786), pp.9-10.

${ }^{34}$ Phillips, Society and Sentiment, p.17.

${ }^{35}$ Grossman, 'Anecdote and History', p.157.

${ }^{36}$ See Dyer, British Satire, 32. As he points out though, Peter's 'colloquial, semi-doggerel style, connect[s] him to more popular traditions' in a way that aligns his work with populist cheap-print forms.

${ }^{37}$ David Higgins, 'Celebrity, Politics and the Rhetoric of Genius' in Romanticism and Celebrity Culture 1750-1850, ed. Tom Mole, (Cambridge: Cambridge Univ. Press, 2009), 41-59 (p.43).

${ }^{38}$ Robert Burns also used the occasion of ridiculing Warton's poems to George III for making political points. See Nigel Leask, Robert Burns and Pastoral: Poetry and Improvement in Late Eighteenth-Century Scotland (Oxford, 2010), p.141.

${ }^{39}$ Gallagher, "'Partial to Some One Side': The Advice-to-Painter Poem as Historical Writing", ELH 78.1 (Spring, 2011), 79-101 (p.80, p.98). See also her full length study Historical Literatures: Historical Literatures: Writing About the Past in England, 1660-1740 (Manchester: Manchester UP, 2012).

${ }^{40}$ Adam Potkay, The Fate of Eloquence in the Age of Hume (Ithaca: Cornell University Press, 1994), p.8

${ }^{41}$ Thomas Warton, Poems on Various Subjects (London: G \& J. Robinson, 1791), p.244 
${ }^{42}$ Instructions to a Celebrated Laureat; Alias the Progress of Curiosity; Alias A Birth-Day Ode; Alias Mr Whitebread's Brewhouse, by Peter Pindar Esq, $8^{\text {th }}$ edition, (London: J \& A M'Lean, 1788) p.8

${ }^{43}$ Ode Upon Ode; Or, A Peep at St James's; Or, New Year's Day; Or What you Will in The Works of Peter Pindar Esq 3 volumes, (London: J. Walker, 1797), vol.1, p.383-4.

${ }^{44}$ Barrell, Spirit of Despotism, 121.

${ }^{45}$ Vincent Carretta, George III and the Satirists from Hogarth to Byron (Athens: University of Georgia Press, 1990), p.269, p.5.

${ }^{46}$ Carretta, George III and the Satirists, p.280.

${ }^{47}$ Carol Percy, 'The King's Speech: Metalanguage of Nation, Man and Class in Anecdotes about George III', English Language and Linguistics 16.2 July 2012, 281-299 (p.296). doi:

10.1017/S1360674312000068.

${ }^{48}$ Barrell, Spirit of Despotism, 123-4.

${ }^{49}$ Brother Peter to Brother Tom. An Expostulatory Epistle By Peter Pindar Esq, $3{ }^{\text {rd }}$ edition, (London: G. Kearsley, 1788), p.13.

${ }^{50}$ The Royal Tour; Or, Weymouth Amusements; A Solemn and Reprimanding Epistle to the Laureat by Peter Pindar Esq. (Dublin: W Porter, 1796), p.iii

${ }^{51}$ Dyer notes that 'no poet's practice conveys more than Wolcot's how radically pseudonymity can differ from anonymity' (British Satire, 37).

${ }^{52}$ For a survey of key scholarship, see Emma Vincent Macleod, 'British Attitudes to the French Revolution', The Historical Journal 50.3 (Sept., 2007), 689-709. DOI: 10.1017/S0018246X07006310.

53 Jennifer Mori, 'Languages of Loyalism: Patriotism, Nationhood and the State in the 1790s', English Historical Review 118.475 (Feb. 2003), 33-58 (p.33). See also Kevin Gilmartin, Writing Against

Revolution: Literary Conservatism in Britain, 1790-1832 (Cambridge: Cambridge University Press, 2007)

${ }^{54}$ Grimes, "Verbal Ju-Jitsu", 174.

${ }_{56}^{55}$ Grimes, "Verbal Ju-Jitsu", 182. 